\title{
MITOS TOKOH PEREMPUAN LAKON ABDULMULUK JAUHARI TEATER DULMULUK TUNAS HARAPAN
}

\author{
Tri Puji Handayani \\ Program Pascasarjana \\ Institut Seni Indonesia Surakarta \\ JI. Ki Hadjar Dewantara No. 19 Kentingan, Jebres, Surakarta, 57126
}

I Nyoman Murtana

ISI Surakarta

\begin{abstract}
ABSTRAK
Penelitian berjudul "Mitos Tokoh Perempuan Lakon Abdulmuluk Jauhari Teater Dulmuluk Tunas Harapan" ini menganalisis tentang tokoh perempuan yang dimainkan oleh aktor laki-laki dan mitos tokoh perempuan dalam lakon Abdulmuluk Jauhari. Dengan menggunakan teori semiotika untuk menjawab permasalahan tersebut maka peneliti membuat pertanyaan dalam rumusan masalah yang berkaitan dengan: bagaimana materi mitos wicara tokoh perempuan dalam lakon Abdulmuluk Jauhari pertunjukan teater Dulmuluk kelompok Tunas Harapan. Penelitian ini menggunakan teori semiotika Roland Barthes untuk melihat analisis tokoh perempuan dalam lakon Abdulmuluk Jauhari. Hasil penelitian ini memberikan pemahaman yaitu (1) Tokoh perempuan yang dimainkan oleh aktor laki-laki menampilkan sosok perempuan dengan menggunakan kostum, make-up, hair style, gerak dan nada yang menyerupai perempuan. Tunas Harapan dalam menampilkan tokoh perempuan melalui aktor laki-laki memiliki simbol-simbol kebudayaan yang disampaikan melalui tokoh perempuan. (2) Tunas Harapan menampilkan tokoh perempuan berdasarkan ideologi gender yang menghadirkan mitos perempuan, yaitu perempuan sebagai kesetaraan gender, perempuan sebagai sosok pemberani, perempuan sebagai sosok penguasa, dan perempuan sebagai penyelamat.
\end{abstract}

Kata kunci: Teater Dulmuluk, Tokoh Perempuan, Mitos.

\begin{abstract}
The research entitled "Mitos Tokoh Perempuan Lakon Abdulmuluk Jauhari Teater Dulmuluk Tunas Harapan " analyzed the female characters played by male actors and the myth of a female character in Abdulmuluk Jauhari's play. By using semiotic theory to answer these problems, the researcher makes a question in the formulation of the problem related to: how is the material of the myth of the talk of female characters in Abdulmuluk Jauhari's play Dulmuluk theater group Tunas Harapan. This study uses Roland Barthes's semiotic theory to look at the analysis of female characters in Abdulmuluk Jauhari's play. The results of this study provide understanding, namely (1) The female figure played by male actors displays a female figure using costumes, make-up, hair styles, movements and tones that resemble women. Tunas Harapan in presenting female characters through male actors has cultural symbols conveyed through female characters. (2) Tunas Harapan presents women leaders based on gender ideology that presents myths of women, namely women as gender equality, women as brave figures, women as figures of rulers, and women as saviors.
\end{abstract}

Keywords: Theater Dulmuluk, Female Leader, Myth.

\section{A. Pengantar}

Perempuan selalu memiliki sisi menarik untuk dikaji, realitas bahwa hadirnya emansipasi adalah salah satu bukti bahwa adanya usaha untuk menyetarakan apa yang selama ini dibedakan. Spock dalam Budiman mengatakan, bahwa perempuan pada hakikatnya hanya dapat mengerjakan sesuatu yang diulang-ulang, pekerjaan tidak menarik, merasa bahagia kalau tidak agresif tidak hanya secara seksual namun juga dalam kehidupan sosial, pekerjaan, dan tugasnya sebagai ibu (Budiman, 1982:6-8).

Berbeda dengan pernyataan Budiman, dalam teater Dulmuluk kelompok Tunas Harapan lakon Abdulmuluk Jauhari, tokoh perempuan ditampilkan memiliki peran penting. Kehadiran tokoh perempuan dalam pertunjukan ini tidak hanya sekedar pelengkap atau pendamping laki-laki. Perempuan dalam lakon ini mampu menyelamatkan keluarganya. Keberanian yang dimiliki oleh tokoh prempuan dapat 
membebaskan Abdulmuluk dan merebut kembali kekuasaannya. Karakter tersebut lazimnya diperankan oleh tokoh laki-laki. Penokohan tersebut merupakan bukti bahwa perempuan ditempatkan pada posisi penting dalam lakon ini. Tokoh perempuan tersebut bernama Siti Rafeah.

Siti Rafeah berperan sebagai istri kedua Abdulmuluk. Siti Rafeah dalam penyerangan Sultan Syabudin ke Negeri Berbari berhasil melarikan diri dan melakukan penyamaran untuk membebaskan suaminya, Abdulmuluk. Siti Rafeah dalam usaha membebaskan suaminya melakukan penyamaran sebagai seorang laki-laki bernama Durjauhari. Durjauhari merupakan seorang penjoget atau penari dan tukang kayu yang berhasil mengalahkan Bahsan Pendengki sehingga diangkat menjadi prajurit oleh Sultan Jamaludin. Selanjutnya, Durjauhari melakukan penyamaran sebagai pedagang yang berdagang di Negeri Hindustan. Penyamaran ini dilakukan Durjauhari untuk mempengaruhi musuh, sehingga bisa membebaskan suaminya dari tahanan Sultan Syabudin.

Kelompok teater Dulmuluk saat ini mayoritas sudah menampilkan tokoh perempuan yang dimainkan oleh perempuan, tetapi kelompok Tunas Harapan masih menampilkan semua tokoh melalui aktor lakilaki. Teater Dulmuluk kelompok Tunas Harapan menampilkan tokoh perempuan dalam pertunjukan dimainkan oleh aktor laki-laki. Selain itu, tokoh perempuan yang dimainkan oleh aktor laki-laki dalam pertunjukan ini kembali melakukan penyamaran sebagai laki-laki. Siti Rafeah dalam lakon Abdulmuluk Jauhari digambarkan seorang perempuan selanjutnya melakukan penyamaran sebagai laki-laki. Aktor lakilaki dalam pertunjukan tidak hanya berperan sebagai tokoh perempuan tetapi juga berperan sebagai lakilaki dalam pertunjukan. Hal ini dapat diasumsikan bahwa kelompok Tunas Harapan menyampaikan ideologi tentang perempuan melalui tokoh perempuan dalam lakon Abdulmuluk Jauhari kepada masyarakat. Kehadiran tokoh perempuan yang dimainkan laki-laki semakin mempertegas bahwa tokoh perempuan dalam lakon Abdulmuluk Jauhari memiliki mitos yang ingin disampaikan oleh kelompok Tunas Harapan dalam pertunjukannya.

Kebudayaan dalam masyarakat Palembang menyatakan perempuan harus dijaga dalam pergaulan ataupun lawan jenis (Yohana, wawancara 20 November 2014). Kehadiran perempuan di tempat umum menjadi beban moral tersendiri bagi orang tua, bahkan keluarganya di Palembang. Perempuan ditabukan untuk keluar malam dan hanya bertugas di belakang mengurusi keperluan dapur (Berlian, wawancara 15 Agustus 2014). Kondisi ini tampaknya juga turut membentuk mentalitas perempuan untuk tidak ikut serta dalam berbagai kegiatan, termasuk seni pertunjukan. Berbagai pendapat negatif muncul ketika perempuan terlibat dalam seni pertunjukan. Pernyataan-pernyataan tersebut akhirnya membangun kekhawatiran yang menghasilkan mitos dalam masyarakat Palembang. Hal ini membuat seniman yang masih meyakini mitos tersebut tetap mempertahankan nilai-nilai yang dibangun oleh mitos wicara masyarakat Palembang.

Menurut Liliweri, nilai merupakan salah satu unsur dasar pembentuk orientasi budaya, dan norma merupakan keyakinan kelompok tentang bagaimana para anggota harus bersikap dalam konteks tertentu yang telah disepakati (Liliweri, 2014: 81). Oleh karena itu, nilai dan norma yang berlaku di masyarakat sangat menentukan peran laki-laki dan perempuan. Seniman yang masih menganut nilai tradisi menganggap tradisi sebagai sesuatu yang agung dan klasik, karena memiliki nilai spiritual dan menjadi sesuatu yang kramat, sehingga dipertahankan. Pementasan Dulmuluk biasanya dilakukan semalam suntuk mulai pukul 20:00 sampai pukul 04:00, menyebabkan perempuan tidak memungkinkan terlibat dalam teater ini. Kemunculan perempuan dalam pertunjukan Dulmuluk jelas melanggar nilai dan norma yang dianut oleh seniman tersebut. Tunas Harapan merupakan salah satu kelompok teater Dulumuluk yang masih aktif, namun tetap menganut nilai tradisi dalam pertunjukan. Kelompok ini menampilkan semua pemain laki-laki dengan alasan masih mempertahankan pakem pertunjukan Dulmuluk dalam pertunjukannya, yaitu tetap menggunakan syair, iringan musik sederhana, dan semua aktor laki-laki. Pertunjukan Dulmuluk yang dimainkan oleh semua aktor laki-laki sejak dulu dan sampai sekarang masih dilakukan (Alias, wawancara 11 Januari 2015).

Ketika tokoh perempuan harus ditampilkan, laki-laki yang berperan sebagai tokoh perempuan menggunakan kostum layaknya perempuan dan menggunakan make-up seperti perempuan dengan tambahan rambut panjang sebagai penutup kepala. Suara dikecilkan sehingga mirip perempuan dan melakukan gerak tubuh seperti perempuan. Tokoh perempuan ditampilkan melalui pandangan laki-laki yang menyerupai tingkah laku perempuan. Hal semacam ini menunjukkan adanya perbedaan antara kategori 'perempuan' sebagai fiksi buatan lelaki dan kategori 'perempuan' dalam peran keseharian. Tokoh 


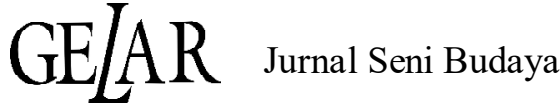

perempuan yang ditampilkan atau dimainkan oleh aktor laki-laki membuat hilangnya sosok perempuan. Yudiaryani menegaskan, bahwa tokoh perempuan yang dimainkan laki-laki di atas panggung adalah pembenaran hilangnya sosok perempuan (Yudiaryani, 2012: 378).

Jeanie Forte mengutip dalam esainya The Laugh of the Medusa, bahwa pertunjukan teater penting untuk membicarakan perempuan. Cixous mengajak kaum perempuan untuk merebut kembali posisi tubuh dan cara penggambarannya. Tubuh harus 'mendengar' apa yang ditulis melalui tubuhnya. Tubuh perempuan bukan sekedar objek rekayasa, tubuh perempuan adalah media ungkap budaya di mana perempuan membangun subjektivitasnya (Yudiaryani, 2012:382-384). Sajian pertunjukan tokoh perempuan yang dimainkan oleh aktor laki-laki dalam pertunjukan kelompok Tunas Harapan jelas menggambarkan makna mitos yang ingin disampaikan oleh seniman melalui masyarakat pendukungnya.

Tokoh perempuan yang dimainkan oleh aktor laki-laki dalam setiap adegannya menghadirkan makna mitos yang ingin disampaikan kelompok Tunas Harapan dalam pertunjukan. Mitos tersebut disampaikan melalui bahasa dan tanda yang disampaikan tokoh perempuan dalam pertunjukan. Roland Barthes menjelaskan, bahwa bahasa membentuk kondisi tertentu untuk menjadi mitos, yaitu secara semiotis dicirikan oleh hadirnya sebuah tataran signifikasi yang disebut sebagai sistem semiologis tingkat kedua, penanda-penanda berhubungan dengan petanda-petanda sedemikian sehingga menghasilkan sebuah tanda (Barthes, 1983:109). Melalui pernyataan tersebut, tokoh perempuan yang dimainkan oleh aktor laki-laki dianalogikan sebagai sebuah tanda yang dimuati mitos.

Penanda-penanda dari sistem semiotis tingkat kedua tersebut disebut retorik atau konotator yang tersusun dari tanda-tanda pada sistem pertama yang merupakan aspek material dari mitos (Barthes, 1981:91). Selanjutnya, petanda-petanda itu sendiri dapat dinamakan fragmen ideologi. Pemahaman Barthes tersebut menunjukkan bahwa mitos merupakan cerita, pesan dan komunikasi yang menyatakan bahwa mitos erat kaitannya dengan retorika (gaya bicara). Pada sisi lain, Barthes mempertegas kedudukan mitos dalam semiotika yang menyatakan bahwa mitos merupakan sistem komunikasi yang artinya mitos adalah pesan. Hal ini dapat memberikan pandangan bahwa sesungguhnya mitos tidak pernah menjadi konsep atau ide, mitos adalah sebuah bentuk.

Penjelasan Barthes tentang mitos tersebut menunjukkan bahwa mitos adalah sebuah bentuk. Mitos tersebut dapat berupa sebuah bentuk pesan, bentuk komunikasi, dan bentuk cara bercerita (retorika). Bentuk-bentuk tersebut artinya membutuhkan sebuah media. Media dapat berupa bahasa, tulisan, gambar dan lain-lain. Hal ini menunjukkan tokoh perempuan merupakan rangkaian mitos dalam pertunjukan teater Dulmuluk yang ditampilkan kelompok Tunas Harapan untuk menyampaikan pesan makna.

\section{B. Pandangan Umum tentang Perempuan}

Masyarakat Palembang yang merupakan suku Melayu dan mayoritas beragama Islam sangat menjaga perempuan dalam kehidupan bermasyarakat. Hal ini dijelaskan, bahwa dalam tradisi kebudayaan masyarakat Palembang, menganggap perempuan itu harus dijaga dalam pergaulan ataupun lawan jenis (Yohana, wawancara 20 November 2014). Selanjutnya, dalam kesenian perempuan juga mengalami keterbatasan. Perempuan boleh melakukan kesenian dengan sekelompok perempuan, tetapi ditabukan jika bertemu dengan sekelompok laki-laki (Ely, wawancara 11 Agustus 2014). Aturan-aturan yang berlaku dalam masyarakat berdasarkan kebudayaan setempat, akhirnya membentuk mentalitas masyarakat itu sendiri. Masyarakat akhirnya membatasi akses perempuan untuk tampil ditempat umum dengan sendirinya.

Dilihat dari latar belakang sosial dan budaya, penduduk asli Palembang yang belum banyak menggunakan ilmu pengetahuan dalam memecahkan suatu permasalahan di dalam hidupnya. Unsur agama dan kepercayaan di daerah setempat ikut andil dalam segala aspek kehidupan terutama di kampungkampung dan telah memberikan warna yang jelas dalam kehidupan sosial kulturnya. Hal ini yang menyebabkan beberapa seniman masih sangat mematuhi adat dalam masyarakat. Dalam hal agama, sebagian besar penduduk kota Palembang memeluk agama Islam. Namun masih tampak adanya sisa-sisa sistem religi (kepercayaan) yang asli dari zaman sebelumnya, sebelum masuk Islam. Sisa-sisa itu dapat diketahui pada sebagian masyarakat yang masih memegang teguh larangan-larangan yang sifatnya "pamali" dalam kehidupan kesehariannya. Hal tersebut merupakan salah satu alasan mengapa perempuan dilarang untuk tampil dalam seni 
pertunjukan, karena banyaknya pandangan negatif ataupun dianggap melanggar larangan-larangan (pamali).

Dalam seni pertunjukan, perempuan sebetulnya seringkali dikesampingkan dan hanya sebagai bayang-bayang kabur, meskipun perempuan juga memiliki andil di dalamnya. Akses perempuan untuk terlibat dalam seni pertunjukan sangat terbatas, karena seni pertunjukan yang ada di desa-desa lebih besar digerakkan oleh kaum laki-laki, sementara perempuan hanya sebagai pendukung yaitu menyiapkan makanan dan minuman untuk para pemain. Kehadiran perempuan dalam dunia seni pertunjukan merupakan sesuatu yang bersentuhan langsung dengan sistem normatif. Perempuan dianggap tabu dalam seni pertunjukan, karena banyaknya asumsi negatif jika perempuan ikut serta bermain dalam pementasan seni pertunjukan. Perempuan tidak hanya diperlihatkan lebih sedikit beraktivitas di luar rumah dibandingkan laki-laki, tetapi secara umum mereka juga tidak banyak dimunculkan (dalam Joanne, 2010:29).

\section{Teater Dulmuluk Kelompok Tunas Harapan}

Pertunjukan teater merupakan hasil dari pencarian, perenungan serta penelaahan dari apa saja, inspirasi karya tersebut sangat erat kaitannya dengan keterkaitan sang pengkarya terhadap suatu obyek ide penciptaan. Ide, gagasan, material, perlengkapan, subyek, obyek dan hal lain dalam karya seni merupakan sesuatu yang signifikan dan memberi pengaruh besar terhadap bangunan estetika sebuah karya seni. Teater sebagai sebuah karya seni akan sangat ditentukan oleh bangunan estetika sebagai penopangnya.

Tunas Harapan merupakan salah satu kelompok teater Dulmuluk yang masih tetap bertahan dan eksis di Palembang. Teater ini dipimpin oleh Alias yang terbentuk pada tahun 1993. Alias merupakan penerus ke-7 teater Dulmuluk di Pemulutan. Kelompok ini merupakan salah satu kelompok Dulmuluk yang masih tetap eksis di Palembang khususnya di Kecamatan Pemulutan. Kelompok ini masih menganut nilai tradisi dan tetap mempertahankan pakem dalam pertunjukannya. Seniman yang masih menganut nilai tradisi menganggap tradisi sebagai sesuatu yang agung, karena memiliki nilai spiritual dan menjadi sesuatu yang kramat, sehingga dipertahankan. Nilai tradisi ini tidak terlepas dari pengaruh latar belakang sosial dan budaya masyarakat sendiri. Achmad menjelaskan, bahwa teater tradisional merupakan teater yang lahir, tumbuh dan berkembang di suatu daerah etnik, yang merupakan hasil kreativitas kebersamaan dari suatu suku bangsa di Indonesia (Achmad, 2006:4). Hal ini yang akhirnya mempengaruhi perkembangan dan menyebabkan kelompok Tunas Harapan masih tetap mempertahankan pakem dalam pertunjukannya.

Kelompok ini dalam pertunjukannya masih dimainkan oleh semua aktor laki-laki, tokoh perempuan juga masih dimainkan oleh aktor laki-laki. Selanjutnya, masih menggunakan syair saat berdialog dan memakai kostum Dulmuluk lama. Iringan musik terdiri dari panjak (biola), bende atau tetawak (gong), gendang kecil, jidor atau beduk (bass dram), dan dram (senar) yang sederhana (Alias, wawancara 11 januari 2015). Alias juga menegaskan, bahwa pertunjukan Dulmuluk yang dimainkan oleh semua aktor laki-laki merupakan aturan sejak dulu dan sampai sekarang masih dilakukan (Alias, wawancara 11 Januari 2015). Hal ini yang akhirnya mempengaruhi perkembangan dan menyebabkan kelompok Tunas Harapan masih tetap mempertahankan tampilan pertunjukannya. Secara tidak langsung, tokoh perempuan yang dimainkan lakilaki masih tetap ditampilkan dengan tujuan untuk tetap konsisten menjaga bentuk pertunjukan dan aturanaturan atau pakem dalam pertunjukannya.

Tokoh perempuan dan tokoh laki-laki dalam pertunjukan teater Dulmuluk sebetulnya memiliki tingkatan yang setara. Tokoh perempuan juga memiliki posisi sendiri dalam pertunjukan teater Dulmuluk. Namun, pandangan masyarakat khususnya seniman kelompok Tunas Harapan yang masih tetap menganut konsep tradisi menganggap perempuan ditabukan dalam pertunjukan ini. Aturan-aturan yang berlaku dalam masyarakat kebudayaan setempat, akhirnya membentuk pandangan masyarakat itu sendiri. Hal ini yang kemudian masih dilakukan oleh kelompok Tunas Harapan yang masih menampilkan semua aktornya laki-laki, karena terus menjaga aturan-aturan yang telah ada dan menganggap tabu ketika perempuan ikut tampil dalam pertunjukan teater Dulmuluk. Hal ini juga ditegaskan Arfan, hadirnya tokoh perempuan yang dimainkan oleh aktor laki-laki karena banyaknya pandangan negatif jika perempuan terlibat dalam seni pertunjukan itu sendiri (Arfan, wawancara 20 Mei 2015).

\section{Sinopsis Lakon Abdulmuluk Jauhari}

Lakon Abdulmuluk Jauhari secara keseluruhan terdiri dari 52 adegan. Lakon ini berasal dari buku "Syair Abdulmuluk" yang mengisahkan 


\section{GE[AR Jumal Sori Bublya}

tentang seorang tokoh bernama Abdulmuluk Jauhari. Oleh karena itu, lakon ini berjudul Abdulmuluk Jauhari. Lakon ini juga pernah dipentaskan kelompok Tunas Harapan dengan judul Selendang Putih (Alias, wawancara 11 Januari 2014).

Lakon Abdulmuluk Jauhari merupakan cerita tentang kehidupan Abdulmuluk anak Abdulhamid. Cerita ini berawal dari Abdulhamid yang memerintah Negeri Berbari. Abdulhamid memiliki seorang putra bernama Abdulmuluk Jauhari. Abdulhamid dalam memerintah Negeri Berbari dibantu oleh kedua saudaranya, yaitu Wasir Mansur sebagai penasehat kerajaan dan Abdul Majid sebagai wakil Sultan. Selama pemerintahan Abdulhamid, Negeri Berbari mengalami kemajuan dan kemakmuran.

Suatu hari Negeri Berbari kedatangan dua orang saudagar dari Negeri Hindustan yang hendak berniaga. Namun, kedua saudagar ini menipu dengan menjual barang-barang yang telah rusak. Akhirnya kedua saudagar ini diadili dan dijatuhi hukuman penjara, karena saudagar Hindustan sudah tua, mereka pun meninggal di dalam penjara. Berita meninggalnya saudagar Hindustan membuat Raha Hindustan marah dan hendak menyerang Negeri Berbari. Melihat kerajaan Berbari yang sangat kuat, penyerangan ditahan oleh Raja Hindustan.

Abdulhamid yang merasa sudah tua segera menikahkan Abdulmuluk dengan Siti Rohmah anak dari Abdul Majid, adik Abdulhamid yang telah meninggal dunia. Setelah pernikahan Abdulmuluk, Abdulhamid meninggal dunia. Negeri Berbari dipimpin oleh Abdulmuluk, tetapi karena masih dalam suasana duka Abdulmuluk meminta untuk berlayar ke asing Negeri untuk menghibur diri dan kerajaan diserahkan kepada Wasir. Perjalanan Abdulmuluk dengan didampingi kedua hadam terhenti di Negeri Ban. Abdulmuluk bertemu dengan Siti Rafeah anak dari Sultan Arabi yang memerintah Negeri Ban dan akhirnya menikah. Setelah itu, Abdulmuluk kembali ke Negeri Berbari dan memimpin kerajaan.

Selama Abdulmuluk Berlayar keasing Negeri, kerajaan Berbari yang diserahkan kepada Wasir yang sudah tua, karena tidak pernah dilakukan latihan menyebabkan angkatan perang menjadi lemah. Raja Hindustan yang menyadari keadaan ini menyiapkan pasukannya untuk menyerang Negeri Berbari. Abdulmuluk kemudian diserang oleh Sultan Syabudin, yaitu Raja Hindustan yang menuntut balas kematian saudagar Hindustan. Penyerangan ini dimenangkan oleh Sultan Syabudin, Abdulmuluk, Siti Rahma dan Wasir ditangkap dan dibawa ke Negeri Hindustan. Istri
Abdulmuluk, yaitu Siti Rafeah berhasil melarikan diri dan berencana untuk membebaskan suaminya.

Siti Rafeah berhasil melarikan diri dengan membunuh anak Wasir untuk mengelabuhi Sultan Sahabuddin seolah-olah telah bunuh diri. Siti Rafeah yang sedang hamil tujuh bulan melarikan diri ke hutan Puri dengan membawa sebilah pedang suaminya. Di dalam perjalanan Siti Rafeah bertemu seekor harimau, Siti Rafeah mengeluarkan ilmu sirap (sihir) dan membuat harimau tertidur. Selanjutnya dengan sigap mengangkat pedangnya dan menusuk perut harimau hingga mati. Siti Rafeah memotong sehelai misa (kumis) harimau yang telah mati lalu dililitkan ke pinggang dan membuat Siti Rafeah menjadi bersemangat kembali.

Dalam perjalanannya Siti Rafeah menemukan sebuah rumah milik ulama yang bernama Syah Alban. Di sinilah Siti Rafeah melahirkan anaknya yang diberi nama Abdul Roni. Setelah Abdul Roni berusia 40 hari, Siti Rafeah meneruskan perjalanan menuju Negeri Hindustan untuk membebaskan suaminya yang ditawan di penjara besi. Abdul Roni dititipkan kepada ulama Syah Alban, dengan pesan bila berusia 14 tahun akan dikirim ke Negeri Hindustan dan sebagai pengenal diserahkannya sebuah cincin.

Perjalanan berikutnya, Siti Rafeah bertemu dengan hulubalang tujuh. Siti Rafeah dengan sigap mengeluarkan ilmu sirap (sihir) sehingga semuanya tertidur, lalu dibunuh satu persatu. Hal ini dilakukan Siti Rafeah dengan tujuan untuk mengambil pakaian Hulubalang dan menyamar sebagai laki-laki dengan nama Durjauhari. Setelah meneruskan perjalanan, Durjauhari bertemu dengan Saudagar Basan seorang pedagang yang kaya raya. Durjauhari menyamar sebagai pengambil upahan joget dan menari untuk mengambil semua harta Saudagar Basan.

Selanjutnya, Durjauhari meneruskan perjalanan dan bertemu dengan Sultan Jamaluddin pimpinan Negeri Berbaham. Sultan Jamaluddin menjelaskan, bahwa Negeri Berbaham hendak dirampas dan dikuasai oleh Bahsan Pendengki, Durjauhari bermaksud untuk menolong Sultan Jamaluddin. Selanjutnya, Durjauhari menyamar sebagai penari untuk menyelidiki dan menangkap Bahsan Pendengki. Keberhasilan Durjauhari menangkap Bahsan Pendengki membuatnya diangkat menjadi Sultan dan dinikahkan dengan adik Jamaluddin yang bernama Siti Arohalbani.

Setelah pernikahannya, Durjauhari meminta izin untuk berangkat ke Negeri Hindustan dengan tujuan berdagang. Sesampai di Negeri Hindustan semua barang dagangannya dirampas dan disiksa 
oleh Sultan Sahabuddin. Durjauhari memohon belas kasih untuk dilepaskan oleh Sultan Sahabuddin dengan perjanjian akan kembali membawakan barangbarang yang lebih bagus. Selanjutnya, Durjauhari kembali ke Negeri Berbaham dan memohon kepada Jamaluddin agar dibolehkan berlayar sekali lagi ke Negeri Hindustan untuk membalas perbuatan yang telah dilakukan Sultan Sahabuddin. Permohonan ini dikabulkan oleh Jamaluddin dan dikirimlah 100 prajurit ke Negeri Hindustan mendahului Durjauhari. Setelah selesai semua persiapan, maka berangkatlah Durjauhari menyerang Negeri Hindustan. Peperangan ini dimenangkan oleh Durjauhari kerajaan Hindustan dapat dikalahkan dan Sultan Sahabuddin ditangkap. Selanjutnya, Durjauhari mencari tempat di mana Abdulmuluk dipenjarakan beberapa tahun yang lalu. Ditemukan tiga orang yang masih hidup dipenjara besi, yaitu Abdulmuluk, Siti Rahmah, dan Wasir.

Abdulmuluk sudah dibebaskan dan keadaan negeri aman kembali. Pemerintahan di Hindustan diserahkan kepada Abdulmuluk Jauhari dan dibantu Sultan Jamaluddin. Selanjutnya, Durjauhari memperlihatkan wajah aslinya kepada Abdulmuluk, Jamaluddin, Siti Rahma, dan Siti Arohalbani. Abdulmuluk yang telah hilang ingatan, tidak mengenali wajah isterinya sendiri, Durjauhari bersujud kepada Abdulmuluk dan menceritakan pengalamannya dalam berupaya membebaskan Abdulmuluk dari tahanan Sultan Sahabuddin.

Bagi Durjauhari atau Siti Rafeah, walaupun semua keluarga telah berada di sampingnya, hatinya masih saja sedih mengenang anaknya Abdul Roni yang ditinggal 14 tahun lalu. Menurut perhitungan, sekarang Abdul Roni genap berusia 14 tahun. Keluarga kerajaan yang sedang berkumpul, yaitu Sultan Abdulmuluk Jauhari dan ketiga isterinya, Jamaludin dan isterinya, Sultan Arabi dan isterinya, para Wasir dan dayang-dayang kedatangan empat orang yang menghadap, yaitu tukang kotak dan anaknya, Abdul Roni dan bapak angkatnya. Keempat orang ini meminta keadilan atas perselisihan mereka. Sultan Abdulmuluk menanyakan hubungan keempatnya, lalu Abdulmuluk bertanya kepada saudagar Gandum, kalau Abdul Roni bukan anak kandungnya. Abdul Roni menjelaskan, bahwa bapaknya bernama Abdulmuluk Jauhari, ibunya Siti Rafeah, kakeknya dari sebelah bapak bernama Abdulhamid Syah dan kakeknya dari sebelah ibunya bernama Sultan Arabi, kemudian dikeluarkannya sebentuk cincin peninggalan ibunya sewaktu akan berangkat ke Negeri Hindustan. Mendengar perkataan Abdul Roni dan setelah mengenali cincin miliknya yang pernah diberikan kepada Siti Rafeah, maka Sultan menggendong Abdul Roni dan membawanya ke Siti Rafeah.

Keluarga kerajaan lalu mengadakan perayaan empat puluh hari empat puluh malam untuk merayakan kebahagiaan karena semua telah berkumpul. Datuk Syah Alban dijemput untuk datang ke kerajaan dan dijadikan pemimpin seluruh ulama di Negeri Hindustan, Negeri Berbaham dan Negeri Berbari. Saudagar Gandum diberi hadiah dan modal untuk berdagang sebagai balas jasanya yang telah menyelamatkan Abdul Roni. Saudagar Kotak diberi hadiah juga untuk modal berdagang dan anaknya dijadikan saudara angkat Abdul Roni. Setelah semuanya selesai, maka diadakan perundingan bersama, bahwa Abdul Roni diputuskan ikut kakeknya Arabi ke negeri Ban, Wasir diperintah untuk memimpin Negeri Hindustan, Sultan Abdulmuluk kembali ke negeri Berbari, dan Wasir kembali meneruskan pemerintahan.

Pada penelitian ini, analisis lakon Abdulmuluk Jauhari teater Dulmuluk kelompok Tunas Harapan dilakukan berdasarkan pengamatan pertunjukan. Pertunjukan kelompok Tunas Harapan lakon Abdulmuluk Jauhari dimulai dari adegan Sultan Syabudin yang hendak menyerang Negeri Berbari sampai adegan Siti Rafeah berhasil mengalahkan Sultan Syabudin dan berkumpul kembali dengan keluarganya. Analisis tersebut berdasarkan pengamatan langsung pertunjukan teater Dulmuluk kelompok Tunas Harapan.

\section{E. Tokoh Perempuan dalam Lakon Abdulmuluk Jauhari}

Tokoh merupakan unsur yang paling aktif untuk menggerakkan alur (Dewojati, 2010:169). Soemardjo juga menegaskan, bahwa tokoh digunakan pengarang untuk menjelaskan peristiwa-peristiwa dalam bentuk plot, konflik, ide (gagasan), struktur lakon, setting, dan tema (Soemardjo, 1991:144). Hal ini menjadi salah satu alasan kenapa tokoh merupakan salah satu unsur yang penting untuk dianalisis.

Tunas Harapan menampilkan lima tokoh perempuan dalam pertunjukan lakon Abdulmuluk Jauhari, yaitu Siti Rohmah sebagai istri pertama Abdulmuluk, Siti Rafeah sebagai istri kedua Abdulmuluk, Dayang, Mak Dayang dan si Dayang. Dari beberapa tokoh perempuan tersebut, Siti Rafeah ditampilkan sebagai tokoh penting dalam pertunjukan. Siti Rafeah dalam penyerangan Sultan Syabudin ke Negeri Berbari berhasil melarikan diri dan melakukan penyamaran untuk membebaskan suaminya, 


\section{GE $[A R$ Jurnal Seni Budaya}

Abdulmuluk. Siti Rafeah dalam usaha membebaskan suaminya melakukan penyamaran sebagai seorang laki-laki bernama Durjauhari. Durjauhari merupakan seorang penjoget atau penari dan tukang kayu yang berhasil mengalahkan Bahsan Pendengki sehingga diangkat menjadi prajurit oleh Sultan Jamaludin. Selanjutnya, Durjauhari melakukan penyamaran sebagai pedagang yang berdagang di Negeri Hindustan. Penyamaran ini dilakukan Durjauhari untuk mempengaruhi musuh, sehingga bisa membebaskan suaminya dari tahanan Sultan Syabudin. Oleh karena itu, analisis terhadap tokoh perempuan dalam pertunjukan teater Dulmuluk kelompok Tunas Harapan ditekankan pada tokoh penting perempuan, yaitu tokoh Siti Rafeah. Analisis tokoh perempuan dilakukan pada tanda-tanda, yaitu kata, nada, mime, gesture, gerak, make-up, hair style, dan kostum. Pemilihan tanda ini berdasarkan dengan tanda yang berhubungan langsung dengan aktor.

\section{Kata (Bahasa)}

Pada beberapa adegan dalam lakon Abdulmuluk Jauhari terdapat pengulangan syair maupun dialog. Salah satu syair yang mengalami pengulangan di beberapa adegan, yaitu syair yang di bawakan Siti Rafeah ketika sedang mempengaruhi musuhnya, sehingga bisa tertidur dan berhasil dikalahkan. Syair tersebut selalu diucapkan ketika Siti Rafeah akan mempengaruhi musuhnya, sehingga bisa tertidur dan bisa dikalahkan. Hal ini menunjukkan Siti Rafeah mampu menguasai musuhnya melalui syair yang dibawakan.

Selain itu terdapat dialog yang juga mengalami pengulangan di beberapa adegan, yaitu Siti Rafeah yang sedang menyamar sebagai Durjauhari seorang pengambil upahan joget dan menari berusaha meyakinkan lawan bicaranya. Hal ini juga menunjukkan Siti Rafeah seorang pemberani, karena mampu meyakinkan lawan bicaranya. Selain itu, Durjauhari yang merupakan sosok laki-laki yang menampilkan sifat perempuan. Hal ini menunjukkan laki-laki dan perempuan mampu melakukan hal yang sama.

Bahasa atau dialog yang digunakan dalam lakon Abdulmuluk Jauhari secara tidak langsung menggambarkan kebudayaan kesenian itu sendiri. Hal ini terlihat melalui syair yang digunakan saat berdialog. Pengulangan dialog yang sering dilakukan merupakan ciri dari masyarakat suku Melayu. Orang Melayu memiliki kebiasaan mengulangi lagu-lagu, ilustrasi pepatah atau kata-kata kiasan pada waktu istirahat (Marsden, 2008:184).

\section{Nada}

Siti Rafeah menggunakan bahasa Melayu dalam interaksinya dengan tokoh lain. Nada bicara Siti Rafeah yang memiliki nada yang lembut ketika berdialog, seperti percakapan-percakapan perempuan pada umumnya mengandung gaya dan makna untuk menampakkan karakter seorang yang lembut pada tokoh ini. Dari dialog pertunjukan lakon Abdulmuluk Jauhari, Siti Rafeah menampilkan vokal yang lembut dengan tetap menjaga kontrol tempo vokal dalam penyampaian saat berdialog. Selanjutnya, tuturan yang lembut dilihat dari dialog yang dibawakan Siti Rafeah dalam setiap adegan. Proses untuk mengungkapkan suara yang lemah lembut merupakan pencapaian citra sebagai perempuan. Hal yang sama juga dilakukan ketika Siti Rafeah menyamar sebagai Durjauhari. Durjauhari tetap berdialog dengan vokal yang lembut. Hal ini menggambarkan bahwa laki-laki maupun perempuan mampu melakukan hal yang sama.

\section{Mime}

Siti Rafeah dalam pertunjukan teater Dulmuluk lakon Abdulmuluk Jauhari berupaya membangun suasana pertunjukan melalui mime yang disampaikan. Pada adegan Siti Rafeah yang sedang menangis meratapi nasibnya, ia berupaya menyampaikan perasaannya dengan mengeluarkan air mata dan ekspresi muka sebagai perubahan emosi. Siti Rafeah dalam pertunjukan ditampilkan sedih meratapi nasib. Sedih meninggalkan anaknya yang baru saja lahir dan sedih karena suaminya ditahan oleh Sultan Sahabuddin di penjara besi. Siti Rafeah meneteskan air matanya, mengeluarkan emosinya yang ditampilkan melalui ekspresi muka dengan dahi berkerut, mata agak menyipit dan nanar, serta terus mengeluarkan air mata. Siti Rafeah menggambarkan seorang ibu yang sedih berpisah dengan anaknya. Selain itu, mime yang ditampilakan Siti Rafeah menunjukkan karakter keibuan yang merupakan pencapaian dalam membangun citra sebagai perempuan. Hal ini juga terjadi ketika Siti Rafeah yang menyamar sebagai Durjauhari disiksa oleh Sultan Sahabuddin. Mime yang disampaikan ketika Durjauhari tidak berbeda dengan ketika menjadi Siti Rafeah. Durjauhari meneteskan air matanya dengan ekspresi muka, dahi berkerut, mata agak menyipit dan nanar, serta terus mengeluarkan air mata.

\section{Gesture}

Siti Rafeah dalam teater Dulmuluk lakon Abdulmuluk Jauhari memiliki gesture tubuh yang tidak 
terlalu tinggi, berkulit hitam dan kurus. Sosok permaisuri dalam pertunjukan ini tidak ditampilkan seperti pada umumnya. Siti Rafeah secara fisik tidak begitu cantik, make-up yang digunakan tidak begitu menampakkan kecantikan Siti Rafeah sebagai seorang istri Raja. Siti Rafeah menunjukkan walaupun dengan gesture tubuh yang tidak tinggi, ia tetap mampu untuk berjuang membebaskan suaminya. Perempuan dalam lakon ini digambarkan memiliki kemampuan yang sama dengan laki-laki yang dalam hal ini sebagai wujud kesetiaan Siti Rafeah terhadap suaminya.

\section{Gerak}

Siti Rafeah dalam teater Dulmuluk lakon Abdulmuluk Jauhari memiliki gerak tubuh yang lemah gemulai dan lembut. Terlihat dari beberapa adegan Siti Rafeah tampil dengan gerakan lembut. Adegan ketika Siti Rafeah menari memperlihatkan gerak tangan yang lemah gemulai. Selain itu, ungkapan estetis dibangun melalui gerak tubuh yang lemah gemulai menyerupai perempuan seperti dalam adegan tersebut. Selanjutnya, gerak yang lemah gemulai merupakan pencapaian yang dilakukan dalam membangun citra sebagai perempuan. Tidak ada perbedaan gerak yang dilakukan ketika Siti Rafeah menyamar sebagai Durjauhari. Gerakan yang dilakukan Siti Rafeah, yaitu posisi tangan kanan yang diputar dengan lembut sembari menghayati alunan musik yang terdengar dan kaki kiri ditekuk ke belakang kaki kanan dengan pantat ditarik ke sebelah kanan membuat gerak Siti Rafeah terlihat gemulai. Gerakan yang sama juga dilakukan saat Siti Rafeah menyamar sebagai Durjauhari. Gerakan ini menggambarkan gerak sosok perempuan yang terlihat dari gerak lemah lembut yang ditampilkan.

\section{Make-Up}

Siti Rafeah dalam pertunjukan teater Dulmuluk lakon Abdulmuluk Jauhari tidak menggunakan rias khusus. Siti Rafeah hanya menggunakan rias sederhana berupa bedak untuk membuat warna kulit agar tidak terlihat pucat, alis, pewarna pipi dan lipstik berwarna merah. Lichte menjelaskan, bahwa pembahasan tentang make-up sendiri sebetulnya hanya menunjuk makna-makna yang dapat didiagnosis (dalam Sahid, 2004:99). Analisis tentang make-up hanya memberikan penjelasan rujukan untuk mengetahui tanda selanjutnya, yaitu tentang wajah atau figur.

Siti Rafeah menggunakan lipstik dan pemerah pipi yang berwarna merah, make-up yang digunakan tidak begitu menyolok. Make-up yang digunakan Siti Rafeah dalam pertunjukan untuk menggambarkan sosok seorang perempuan. Selain itu, make-up yang digunakan Siti Rafeah ditampilkan kelompok Tunas Harapan dengan tujuan untuk menunjukkan aktualisasinya dengan membangun citra diri melalui ungkapan-ungkapan estetis dalam pertunjukannya. Selanjutnya, make-up yang digunakan Siti Rafeah menggambarkan ciri kebudayaan setempat. Siti Rafeah melalui make-upnya digambarkan sebagai sosok perempuan yang telah memiliki suami, sederhana dan setia. Hal ini bisa dilihat dari pernyataan berikut.

"Apabila seorang wanita akan berpergian, bertemu melihat keluarga dan lain keperluan, maka pakaiannya sangat sederhana sekali, make up-nya tidak menyolok, hampir tidak kelihatan...ini pertanda bahwa ibu ini adalah seorang yang sudah bersuami. Seorang wanita yang telah bersuami adalah sederhana dan setia" (Departemen Pendidikan dan Kebudayaan, 1980:58).

Pada penjelasan di atas tampak, bahwa Siti Rafeah ditampilkan berdasarkan sosok perempuan Palembang. Siti Rafeah menggunakan make-up sederhana yang menunjukkan pertanda, bahwa Siti Rafeah seorang perempuan yang bersuami dan seorang ibu yang sederhana dan setia. Selanjutnya, make-up yang digunakan Siti Rafeah dalam penyamarannya sebagai Durjauhari tidak jauh berbeda dengan make-up yang dipakainya sebagai Siti Rafeah. Hal ini menunjukkan tidak ada perbedaan antara lakilaki dan perempuan secara make-up dalam pertunjukan ini.

\section{Hair Style}

Lichte menjelaskan, bahwa gaya rambut seorang tokoh dapat dikaitkan dengan fenomena alam dan budaya (dalam Sahid, 2004:103). Tokoh perempuan, yaitu Siti Rafeah menggunakan kain hitam yang dihiasi manik-manik sepanjang kain sebagai penutup kepala dengan tambahan gandik, yaitu hiasan kepala yang berwarna merah dengan taburan hiasan berwana kuning emas.

Siti Rafeah menggunakan kain sebagai penutup kepala. Kepala merupakan bagian atas dari tubuh yang paling dihormati. Ketika seseorang menutup kepalanya menunjukkan, bahwa ia menjaga kehormatannya. Dalam hal ini, Siti Rafeah menunjukkan sosok seorang ibu dan istri yang menjaga kehormatan serta harga dirinya. 


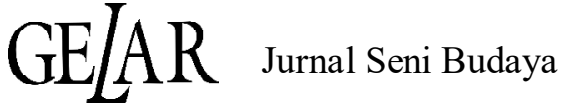

Selanjutnya, Siti Rafeah yang melakukan penyamaran sebagai Durjauhari mengenakan penutup kepala yang berbeda pula. Durjauhari menggunakan tanjak, yaitu penutup kepala yang biasa digunakan oleh laki-laki keturunan kerajaan.

Salah satu ciri kelengkapan seorang raja dan menteri-menteri terutama dapat dilihat dari penggunaan tutup kepala berbentuk segitiga yang menyerupai sebuah mahkota yang disebut tanjak (Kartiwa, 2007:32).

Durjauhari merupakan seorang laki-laki keturunan kerajaan yang tampil menggambarkan kebudayaan Palembang melalui penutup kepala yang dikenakannya dalam pertunjukan.

\section{Kostum}

Busana atau kostum yang digunakan dalam pertunjukan merupakan pakaian yang dikembangkan dari kebudayaan suku Melayu yang ditampilkan ke dalam pertunjukan. Siti Rafeah menggunakan kebaya kurung tangan panjang berwarna kuning dan kain songket merah serta hiasan ikat pinggang dari kain berwarna merah. Baju kurung adalah baju yang lengkap, sehingga orang yang memakainya seolaholah terkurung di dalamnya. Selanjutnya, pakaian ini diubah menjadi kebaya kurung dengan membelah bagian muka, sehingga yang memakai tidak merasa terkurung dan panas (Departemen Pendidikan dan Kebudayaan, 1980:60-61). Dari pernyataan tersebut, Siti Rafeah digambarkan sebagai seorang perempuan dari keturunan kerajaan yang memiliki kebebasan dalam kekuasaan. Selain itu, melalui baju kebaya kurung dan jumlah tujuh kancing baju yang dikenakan Siti Rafeah menampilkan Siti Rafeah sebagai petanda seorang ibu dan istri. Hal ini juga dijelaskan melalui pernyataan berikut.

Apabila kancing bajunya tiga, maka ia berarti bahwa pemakainya itu adalah seorang gadis. Apabila lima kancingnya, maka ini berarti bahwa ia telah bersuami dan apabila kancing bajunya berjumlah tujuh, maka ini berarti bahwa ibu tersebut adalah seorang ibu tauladan. la adalah seorang ibu yang mempunyai banyak pengalaman dalam kehidupannya, mempunyai keluarga besar dan disegani di dalam kalangannya (Departemen Pendidikan dan Kebudayaan, 1980:57).

Selanjutnya, songket yang dikenakan dalam pertunjukan ini menandakan Siti Rafeah berasal dari keturunan bangsawan. Kartiwa menegaskan bahwa songket Palembang yang khas yaitu dengan dipakainya benang-benang emas murni yang menghias pakaian raja dan permaisurinya untuk pakaian kebesaran mereka (Kartiwa, 2007:31).

Siti Rafeah dalam pertunjukan juga mengenakan hiasan pinggang, kalung, dan cincin yang berfungsi sebagai pemanis hiasan kostum yang dikenakannya. Pakaian yang dikenakan perempuan Palembang ada dua macam, yaitu berpergian untuk upacara adat atau bertamu dan lain sebagainya, bila perempuan pergi keluar pakaiannya terdiri dari gelang kaki dari emas, kain songket atau peradan (Departemen Pendidikan dan Kebudayaan, 1980:61). Pernyataan tersebut menunjukkan, bahwa kostum yang dikenakan Siti Rafeah menggambarkan ia sedang di luar rumah.

Penyamaran yang dilakukan Siti Rafeah sebagai Durjauhari membuat perubahan kostum yang dikenakan dalam pertunjukan. Kostum yang digunakan Siti Rafeah saat menyamar sebagai Durjauhari seorang laki-laki yang mengambil upahan joget dan menari, yaitu baju lengan panjang dengan celana panjang berwarna hijau dan hiasan pingang berwarna merah. Pakaian yang dikenakan Durjauhari merupakan pakaian yang berasal dari Palembang, yaitu tuluk belango. Tuluk belango berasal dari dua perkataan, yaitu Tuluk dan Belangnya. Tuluk artinya sesuai atau cocok dan Belangnya artinya corak. Pakaian Tuluk Belango adalah pakaian yang setuluk dengan belang pemakainya atau setuluk dengan corak dari orang yang memakainya. Pakaian yang dikenakan Durjauhari merupakan petanda seorang laki-laki sesuai dengan kostum yang digunakan.

\section{F. Mitos Tokoh Perempuan dalam Lakon Abdulmuluk Jauhari}

Berdasarkan analisis tokoh perempuan dalam lakon Abdulmuluk Jauhari, terdapat ideologi yang akhirnya menampilkan mitos untuk menghadirkan tokoh perempuan dalam pertunjukan. Tokoh perempuan dihadirkan dalam lakon Abdulmuluk Jauhari berdasarkan ideologi kelompok Tunas Harapan yang tetap menampilkan tokoh perempuan melalui aktor laki-laki. Yudiaryani menegaskan, bahwa suatu karya seni berfungsi menyampaikan peran mereka untuk menyampaikan nilai-nilai yang ada di dalam masyarakat tersebut (Yudiaryani, wawancara 7 Agustus 2015). Oleh karena itu, ideologi merupakan 'perekat sosial' yang menjaga kestabilan masyarakat dengan mengikat para anggotanya yang secara kolektif 
menerapkan nilai-nilai dan norma-norma (Murtana, 2010: 16).

Tokoh perempuan yang ditampilkan kelompok Tunas Harapan memiliki ideologi, yaitu ideologi maskulinitas, feminitas dan gender. Ideologi maskulinitas dalam pertunjukan ini menampilkan konstruksi sosial laki-laki dan perempuan yang tersirat erat dengan permasalahan gender. Zimmerman dalam Ritzer dan Goodman menjelaskan, bahwa gender (yaitu perilaku yang memenuhi harapan sosial untuk laki-laki dan perempuan) tidak melekat dalam diri seseorang, tetapi dicapai melalui interaksi dalam situasi tertentu (Ritzer dan Goodman, 2003:413-414). Hal ini menunjukkan Siti Rafeah dalam pertunjukan ditampilkan melalui perilaku laki-laki dan perempuan berdasarkan situasional.

Dari pengamatan tersebut teater Dulmuluk kelompok Tunas Harapan menampilkan mitos tokoh perempuan berdasarkan kesetaraan laki-laki dan perempuan. Hal ini menunjukkan, adanya penegasan yang disampaikan kelompok Tunas Harapan melalui ideologi gender dengan menampilkan tokoh perempuan yang memiliki kemampuan sama dengan laki-laki. Tunas Harapan memiliki ideologi gender yang disampaikan melalui tokoh perempuan dalam setiap adeganya. Selain itu, kelompok Tunas Harapan terlihat tetap menjaga atau mempertahankan ideologi ini dengan selalu menampilkan tokoh perempuan yang dimainkan aktor laki-laki dalam pertunjukan. Ideologi tersebut kemudian menampilkan makna yang menunjukkan kehadiran tokoh perempuan dalam lakon Abdulmuluk Jauhari, yaitu perempuan sebagai kesetaraan gender, perempuan sebagai sosok pemberani, perempuan sebagai sosok penguasa, dan perempuan sebagai penyelamat. Tokoh perempuan ini ditampilkan melalui ideologi yang dimiliki kelompok Tunas Harapan, yaitu ideologi Gender yang kemudian menampilkan makna mitos dalam pertunjukannya melalui tokoh perempuan.

\section{G. Kesimpulan}

Tokoh Perempuan dalam lakon Abdulmuluk Jauhari yang dimainkan oleh laki-laki ditampilkan kelompok Tunas Harapan dalam pertunjukan sebagai tokoh perempuan. Tunas Harapan menampilkan tokoh perempuan yang dimainkan melalui aktor laki-laki dengan tujuan untuk tetap mempertahankan dan melestarikan pertunjukan ini sesuai dengan pakem pertunjukan yang telah ada sebelumnya. Tokoh perempuan yang ditampilkan dalam pertunjukan lakon
Abdulmuluk Jauhari memiliki simbol-simbol pesan dan kebudayaan yang disampaikan melalui setiap interaksi yang dilakukan dalam pertunjukan. Aktor lakilaki yang memainkan tokoh perempuan menggunakan tampilan dan sikap yang menyerupai perempuan. Hal ini dilihat dari kostum, make-up, hair style, gerak, dan nada yang ditampilkan menyerupai perempuan dalam pertunjukan.

Tokoh Perempuan dalam lakon Abdulmuluk Jauhari menampilkan beberapa adegan penting di dalam pertunjukan. Tunas Harapan dalam pertunjukannya menampilkan tokoh perempuan melalui aktor laki-laki. Berdasarkan analisis terhadap lakon Abdulmuluk Jauhari, tokoh perempuan digambarkan memiliki makna mitos yang disampaikan dalam pertunjukan. Tunas Harapan menampilkan makna mitos perempuan, yaitu perempuan sebagai kesetaraan gender, perempuan sebagai sosok pemberani, perempuan sebagai sosok penguasa, dan perempuan sebagai penyelamat. Tokoh perempuan ini ditampilkan melalui ideologi yang dimiliki kelompok Tunas Harapan, yaitu ideologi Gender yang kemudian menampilkan mitos dalam pertunjukannya melalui tokoh perempuan.

\section{KEPUSTAKAAN}

Achmad, A. Kasim. Mengenal Teater Tradisional di Indonesia. Jakarta: Dewan Kesenian Jakarta, 2006.

Barthes, Roland. Elements of Semiology. New York: Hill and Wang, 1981.

Mythologies. New York: Hill and Wang, 1983.

Budiman, Arief. Pembagian Kerja Secara Seksual. Jakarta: PT. Gramedia, 1982.

Departemen Pendidikan dan Kebudayaan. Sejarah dan Kebudayaan Palembang 1. Jakarta: Proyek Penerbitan Buku Sastra Indonesia dan Daerah, 1980.

Dewojati, Cahyaningrum. Drama: Sejarah, Teori dan Penerapannya. Yogyakarta: Javakarsa Media, 2010.

Kartiwa, Suwati. Ragam Kain Tradisional Indonesia Tenun Ikat. Jakarta: PT Gramedia Pustaka Utama, 2007. 


\section{GEAR رumisumbutuse}

Liliweri, Alo. Pengantar Studi Kebudayaan. Bandung: Nusa Media, 2014.

Murtana, I Nyoman. Seni dan Politik: Visi Ideologi Komunis, Humanis, dan Teologis Dalangl Made Jangga dalam Lakon Cupak Ke Swargan. Surakarta: ISI Press Surakarta, 2010.

Ritzer, George dan Goodman, Dovglas J. Teori Sosiologi Modern, terj. Alimandan. Jakarta: Kencana, 2003.

Sahid, Nur. Semiotika Teater. Yogyakarta: ISI Yogyakarta, 2004.

Saleh, Abdullah. dan R. Dalyono, BA. Kesenian Tradisional Palembang Teater Dulmuluk. Palembang: Proyek Pembinaan dan Pengembangan Kesenian Tradisional Palembang, 1996.

Satoto, Soediro. Analisis Drama dan Teater. Yogyakarta: Ombak, 2012.
Yudiaryani. "Perempuan dan Teater: Dongeng dalam Kenyataan." Jurnal Seni dan Budaya Panggung, Vol.17, No. 4 (Desember 2007):375-386.

\section{Narasumber:}

Alias (54), PNS. Pelabuhan Dalam Dusun 1 RT 01 Pemulutan Palembang.

Arfan Suri (49), Seniman. Pelabuhan Dalam Dusun 1 Pemulutan Palembang.

Ely Rudi (55), Seniman. Bukit Siguntang, Palembang.

Saudi Berlian (58), Dosen. Lr. Bakti RT 02 RW 08 Pakjo Palembang.

Yudiaryani (44), Dosen Institut Seni Indonesia Yogyakarta. Bantul Yogyakarta.

Yohana (24), Guru. JI. Segaran Lr. Kuningan No. 92 RT.04 RW. 01 Kelurahan 15 llir, Kecamatan Ilir Timur I, Palembang. 